\title{
Characteristics of the Factors Affecting the Performance of the Global Business Services Sector in Latvia \\ Edite Zile ${ }^{1}$, MBA; Lasma Licite-Kurbe², Dr.oec., associate professor \\ 1, 2Latvia University of Life Sciences and Technologies
}

Abstract. In Latvia, the global business services sector accounts for $2.3 \%$ of GDP, and its share in total service exports is $8 \%$, while the turnover of the sector in 2019 was estimated at EUR 400 mln., which indicates that the global business services sector in Latvia is an important component of the national economy. The global business services sector in Latvia has developed relatively recently, so it has not yet been sufficiently assessed and researched. The aim of the research is to describe the factors affecting the development of the global business services sector in Latvia. The research concluded that the global business services sector in Latvia was promoted by such factors as the availability of labour and low labour costs, as well as a relatively favourable business environment. The potential of the global business services sector in Latvia is also characterized by its advantageous geographical location, especially from the perspective of Scandinavian investors (including in terms of cultural similarities), as well as the foreign language skills of potential employees. The establishment of the Association of Business Service Leaders in Latvia (ABSL Latvia) (the only such an association in the Baltic States that defends the interests of this sector) is also an important driver for the development of the sector.

Keywords: global business services, service centres, shared service centres, PESTLE.

JEL code: F23, F63, F65, F2, O10

\section{Introduction}

In today's globalized world, companies increasingly try to find new ways how to enter the market to sell their goods and services and how to use their skills, talents and resources to enhance their performance. Outsourcing, offshoring and global business services are part of this phenomenon (Oshri I., 2011). Studies show that companies who operate in this sector can reduce costs up to $30 \%$ compared with companies using conventional organizational concepts (Richter P. C., Bruhl R., 2020). In Latvia, the global business services sector accounts for $2.3 \%$ of GDP, and its share in total service exports is $8 \%$, while the turnover of the sector in 2019 was estimated at EUR $400 \mathrm{mln}$. (Zvejnieks O., 2019). This means that in Latvia, the global business services sector is an important contributor to economic growth and an export-capable element of the financial sector. According to ABSL Latvia, about 50 companies operate in this sector, employing about 15000 employees. However, the global business services sector in Latvia has developed relatively recently, so the public often lacks an understanding of global business services, shared service centres, business process outsourcing etc., as well as this sector has not yet been sufficiently assessed and researched.

Although this topic is increasingly researched in the world and presented in the scientific literature (Oshri I., 2011; Oshri I. et al., 2015; Bangemann T. O., 2017; Strikwerda J., 2006; Marciniak R., 2013), in Latvia, however, more attention is paid to this topic in various reports produced by companies that, among other responsibilities, also provide audit services and publish reports on this sector, e.g. Deloitte, PwC. It should be additionally noted that foreign scientific research studies often focus on only one particular kind of global business service, e.g. shared service centres (Richter P. C., Bruhl R., 2017; Rothwell A. T. et al., 2011; Banoun A. et al., 2016; Koval O. et al. 2016; Richter C. R., Bruhl R., 2020), business process outsourcing (Krysinska J. et al., 2018; Zhang Y. et al. 2018; Liu S. et al., 2017); however, there is a lack of comprehensive research in this field. In Latvia, research studies on the global business services sector as a whole are very limited in scope. 
The following hypothesis is put forward - the global business services sector in Latvia has the potential to develop, which is mainly determined by such factors as low labour costs, an advantageous geographical location and the establishment of the Association of Business Service Leaders in Latvia (ABSL Latvia), which represents the interests of the sector.

The aim of the research is to describe the factors affecting the development of the global business services sector in Latvia. To achieve the aim, the following specific research tasks are set: 1) to describe the theoretical aspects of global business services from the perspective of social sciences; 2) to identify the factors affecting global business service activities.

A number of research methods were employed to do the research: monographic and descriptive for theoretical discussion and interpretation of the research results based on scientific findings and theories; analysis and synthesis for examination of problem elements and identification of regularities; induction for making assumptions based on individual elements or facts; deduction for logical systematization and interpretation of empirical data. Statistical analysis methods and PESTLE analysis were used to analyse the factors affecting the global business services sector in Latvia. Given that information on global business service activities in Latvia is limited, the authors of the research conducted interviews with four experts from the global business services sector: a senior investment project manager from the Investment and Development Agency of Latvia (LIAA), an executive director of the Association of Business Service Leaders in Latvia (ABSL Latvia), the head of the Business Support Department of the DNB Service Centre and a business analyst from the Circle K Business Centre.

The present research used the following information sources: research papers from international scientific journals, electronically available national and foreign periodicals focusing on global business service activities, as well as statistical data (Eurostat, CSB), unpublished materials of the Investment and Development Agency of Latvia and statistical data collected by the Association of Business Service Leaders in Latvia (ABSL Latvia).

\section{Factors affecting the performance of the global business services sector in the context of social science theories}

A service centre is formed as the separate business unit of a globally represented organization in order to provide business support functions to its group's companies or legally unrelated entities. The most frequently served business support functions are IT, finance and accounting, customer care, logistics, procurements, HR, and legal. However, these are only the most popular functions: other specific services may derive from a company's core business, including broadcast services, quality control of chemical products, banking services etc. (Business Service Sector..., 2020). The following main kinds of global business services could be distinguished in this sector: centres of excellence, shared service centres, business process outsourcing, IT support and system maintenance services, research \& development centres etc. Besides, global business services are defined as a separate kind of services, which make up a whole sector in Latvia.

To identify the factors affecting the performance of the global business services sector, research employs various social science theories (Garson D., 2008) that explain the development and operation of the sector. One of the best-known theories is the Transaction Cost Theory. The Transaction Cost Theory combines economic theory and management theory to determine the best way for a company to develop in the market (Mclvor R., 2005). The Transaction Cost Theory explains the advantages of producing services within the company or lowering transaction costs as much as possible by using the opportunities provided by the market (outsourcing) (time and financial resources needed for planning and coordinating the tasks 
to be performed) (Leimeister S., 2010). It could be concluded that this theory requires companies to consider the opportunities offered by the market for reducing potential costs. The costs include both labour and infrastructure costs, as well as tax policies. Most often, the focus is placed on labour costs (Oshri I. et al., 2015); however, production and transaction costs, which need to be balanced, should also be taken into account instead of focusing only on economies of scale (Elston T., MacCarthaigh M., 2016).

Two theories pertaining to resources are the Resource-based Theory and the Res ource Dependency Theory. The Resource-based Theory views a company as a set of productive resources. The company's growth is based on the desire to use the company's resources as efficiently as possible. In order for a company's resources to provide a lasting competitive advantage, the resources should meet four preconditions: they should be valuable, rare, difficult to imitate and irreplaceable. This means that a company's competitiveness depends on its ability to obtain and maintain its resources (Cheon M. J. et al., 1995), focusing more on its internal resources. The Resource Dependency Theory, in contrast, focuses mostly on the external environment of a company and states that all companies are to some extent dependent on the impacts of the external environment. External impacts require that external factors control resources (land, labour, capital, information, specific goods or services). Companies need to adapt to environmental uncertainty, tackle the problem of interdependence and manage and control the flow of resources (Cheon M. J. et al., 1995). It can be concluded that companies assess the available resources and assess whether to manage processes within the organization or outsource them based on the theories.

The Core Competency Theory states that core competences are a specific factor that a company considers to be key to its performance. Accordingly, core competences should be difficult for competitors to imitate, could be used regarding many products and markets and should provide benefits and value to the final consumer. Core competencies can take many forms, e.g. a reliable process or close relationships with customers and suppliers (Kawshala H., 2017). In view of the findings of the Core Competency Theory, it is important to assess the locations where companies are able to exploit core competencies in their economic activities in the global business services sector. Core competencies are important in relation to assessment of the abilities and knowledge of a potential workforce. The abilities include technical and business knowledge, management skills, language skills as well as an ability to learn and be innovative. Companies assess the desired and available abilities of potential employees in any particular country, yet often have to provide various specialized training programmes within the company (Oshri I. et al., 2015). It is important for a potential service provision location to have a qualified and capable workforce. Consequently, there is a lot of discussion about collaboration between industry and academia in order to provide potential employees with the specific skills needed (Aman A. et al., 2017).

The Principal-Agent Theory is viewed in the context of an agent representing a person who has delegated powers to the agent. An agent is the one to whom powers have been delegated (Lupia A., 2001). According to the theory, the task of the principal is to develop a set of incentives that the agents consider to be the best possible set of actions in their own interest (from the principal's point of view). This theory is relevant when referring to effective contracting, particularly in the case of outsourcing, as there is little control over the outsourcing provider acting as an "agent" (Pankowska M., 2019).

The Power-Politics Theory focuses on the role of power and politics in decision-making. Power is defined as the potential of one party to influence the other party's actions in specific situations, while politics is viewed as the way the power is exercised (Dibbern J., 2004). Based on this theory, multinational companies in the global business services sector assess the opportunities and risks when choosing a country in which to operate, as the country's legal framework and business environment are of great importance. This theory refers to government support, the attractiveness and accessibility of the business environment (flight 
frequency and duration, time zone difference etc.) (Oshri I. et al., 2015). When choosing a country for potential service providers, companies consider the fact that tax policies and practices vary considerably from country to country (Beaman K. V., 2006).

Based on the social science theories and their application to the global business services sector, it could be concluded that the theories deal with the main factors affecting the performance of the global business services sector: resources and competencies - how they are exploited and taken into account - as well as management and coordination with regard to determining what and how services will be provided. Organizations analyse mostly costs, the business environment, labour availability and specific workforce skills (Oshri et al., 2015). In pursuit of higher competitiveness and due to the attractiveness of potential opportunities, companies often relocate their services without really considering all the possible risks (Senft D., 2013).

Latvia is a popular location for global business services companies due to various factors contributing to this sector. A PESTLE analysis was done to identify the most significant factors affecting the performance of the global business services sector in Latvia.

\section{Factors affecting the global business services sector in Latvia}

Political factors. To foster the development of the global business services sector in Latvia, regular working group meetings are held between the Ministry of Economics, the Investment and Development Agency of Latvia (LIAA), the Riga City Council, the Finance Latvia Association, the Foreign Investors Council in Latvia, the Alliance of Real Estate Developers and industry representatives. On 26 April 2018 , a memorandum on the development of global business services was signed in Riga. The memorandum envisages purposeful cooperation between national institutions, the capital city and the private sector with the aim of contributing to the development and growth of this sector and the creation of new jobs in the sector. The memorandum projects to create 10000 new, high value-added jobs in the global business services sector over five years, emphasizing that these are jobs in internationally recognized and respected companies, with higher salaries than the national average and other guarantees. The memorandum emphasizes the role of such companies in motivating students not to leave the country after graduation, as well as in promoting re-emigration. One year after signing the memorandum, on 18 April 2019, the Association of Business Service Leaders in Latvia (ABSL Latvia) was established with the aim of increasing the role of global business services in Latvia. It should be noted that this is the only association of this kind in the Baltic States, which aims to contribute to public and decision-making institutions' understanding of the contribution of global business services to the economy of Latvia, ensure cooperation with higher education institutions, advocate the opinions of the sector's companies in the public arena, contribute to sharing knowledge of robotic processes and corporate social responsibility, attracting a talented workforce, dealing with immigration issues etc. However, the establishment of the association cannot be considered as a crucial step regarding the development of the sector in Latvia, which will bring immediate results. The authors believe that it is likely that the newly established association alone will not be able to provide such a contribution and influence; therefore, targeted public policies are needed to promote and support this sector. However, in general, the establishment of the association could be viewed as a positive factor in fostering the development of the global business services sector.

On the part of the state, it is mostly the LIAA and the Ministry of Economics that directly work on attracting investors and consider support programmes. To encourage the opening of more global service centres in Latvia, the Cabinet of Ministers has made amendments to the EU funding programme "Support for ICT and non-technological training, as well as for training to facilitate the attraction of investors". The 
amendments apply to training organized by the LIAA, in which foreign investors are interested, and provide for support for training foreign investor employees, which is essential for a daughter company in Latvia to successfully take over processes and knowledge from the parent company. The experts interviewed viewed the support programme offered by the LIAA as a facilitating factor whereby the government seeks to attract companies. Several companies have used this employee training programme and were satisfied with it.

Economic factors. According to unpublished data from the LIAA, $50 \%$ of investors in the global business services sector were the Scandinavian countries (Sweden, Norway, Finland and Denmark). The choice of these countries in favour of Latvia was mainly determined by cost efficiency (Business Guide, 2019), incl. relatively low labour costs, which motivated foreign investors to choose the Baltic States. According to the information summarized in Table 1, it could be concluded that although labour costs in Latvia have steadily increased by $28.6 \%$ from 2016 to 2019, in Estonia the costs were higher (according to Eurostat data, EUR 12.4 in 2012 and EUR 13.4 in 2019), while in Lithuania the costs were lower (EUR 9 in 2018 and EUR 9.4 in 2019), thereby creating some competitive advantages over Latvia. However, on average in the EU-27 in 2019, labour costs were almost three times higher, amounting to EUR 27.7, while in Norway even EUR 50.2 and in Sweden EUR 36.3. This indicates the interest of the Scandinavian countries in hiring employees in Latvia. Besides, according to the data from ABSL Latvia, average earnings in the global business services sector in Latvia totalled EUR 1657 before taxes, which was half the average earnings in the country, thereby motivating potential employees to get involved in companies in the sector (Table 1).

Another important factor affecting investments in Latvia was the availability of labour. According to the data from ABSL Latvia, the number of employees in the sector increased by $10 \%$ in 2019. The vast majority of individuals employed in business service centres are millennials; because this generation grew up in the era of technology, they have had the superpower of being able to easily learn the new systems, IT and digital tools widely used in business service centres (Perkune L., Licite L., 2019; Licite, L., Janmere, L., 2017). Interestingly, that is only a small percentage of people aged $45+$ employed in the sector. This can be explained by the fact there one of the main requirements to be able to work for a service business is English language skills at a professional level. Generation X and Baby Boomer employees are people who have lived in Latvia since the period shortly after World War II, which had major implications on language skills. Accordingly, a large majority of people aged $45+$ are well educated in the Russian language or even German while significantly lacking in English skills. In addition, their ability to adapt to new systems, IT and digital tools might not be as fast since they have not grown up among these new technologies. Nevertheless, there are several business service centres that have started to slowly integrate the $45+$ age group (Business Services Sector..., 2020).

As indicated by the experts interviewed, the current problem is the availability of a qualified workforce in the field of IT. According to a study conducted by ABSL Latvia (2020), the most popular sectors serviced by operational centres based in Latvia are IT and banking, financial services, and insurance (Business Services Sector..., 2020), which indicates that the availability of such specialists is a problem, which is going to be even more acute in the future. In general, there is a great interest from European companies to increase the supply of business services in the IT sector in the Baltics, which would mean some employees will be poached from domestic companies and lead to even higher wages because there are no free IT specialists in the labour market. Against the background of other EU Member States, according to Eurostat data, Latvia had the lowest employment rate of ICT specialists at $1.7 \%$ of the total workforce, compared with the EU average of $3.9 \%$. Compared with the neighbouring countries, $6.0 \%$ of the total workforce in Estonia in 2019 were ICT specialists, while in Lithuania - 3.1 \% (on average in the EU-27 
in 2019 - 3.9 \%). Some business service centres organize internal IT training in order to have the required programming skill sets. In Latvia, higher education institutions have around 7000 IT students each year and nearly 800 graduates, however, this is not enough to meet the demands of the fast growing IT sector. Because of this, people are being recruited also from other countries. According to a study conducted by the ABSL Latvia (2020) at the end of 2019, approximately 750 foreign residents, $7 \%$ of total foreign residents, were employed in companies of the sector under review (Business Services Sector..., 2020).

Table 1

Characteristics of the workforce in Latvia in the period 2016-2019

\begin{tabular}{|l|c|c|c|c|c|}
\hline \multicolumn{1}{|c|}{ Indicator } & $\mathbf{2 0 1 6}$ & $\mathbf{2 0 1 7}$ & $\mathbf{2 0 1 8}$ & $\mathbf{2 0 1 9}$ & $\mathbf{2 0 1 9 / 2 0 1 6}$ \\
\hline Average hourly wages and salaries, EUR & 7.7 & 8.2 & 9.3 & 9.9 & 1.3 \\
\hline Average monthly wages and salaries (gross), EUR & 859 & 926 & 1004 & 1076 & 1.3 \\
\hline Proportion of ICT specialists in the total workforce, \% & 2.8 & 2.8 & 2.6 & 3.1 & 1.1 \\
\hline
\end{tabular}

Source: authors' calculations based on Eurostat and CSB data

The development of the global business services sector is also affected by the development of the property market, as companies in this sector demand high-quality and energy-efficient offices. The development of modern office centres is a critical prerequisite for the development of this sector, and Tallinn and Vilnius are mostly preferred. However, currently (in 2020), according to the experts interviewed, Riga could be considered attractive due to many vacancies for A and B1 class office spaces.

The global business services sector is also affected by competition. According to the 2019 Kearney Global Services Location Index (Digital resonance: the..., 2019), which rates a country's attractiveness as a service provider in four categories (financial attractiveness, workforce skills and availability, the business environment and digital resonance), Estonia ranked $12^{\text {th }}$ among the Baltic States and had proven itself in the digital field, as well as its business environment rating was higher. Lithuania ranked $16^{\text {th }}$ in the index, and unlike Latvia and Estonia, it had the highest financial attractiveness rating, which could be explained by lower average hourly earnings, which was considered an important factor in the country's attractiveness. Latvia ranked $21^{\text {st }}$ in the index and had the lowest digital resonance rating, yet its business environment was more attractive than that in Lithuania (Digital resonance: the..., 2019).

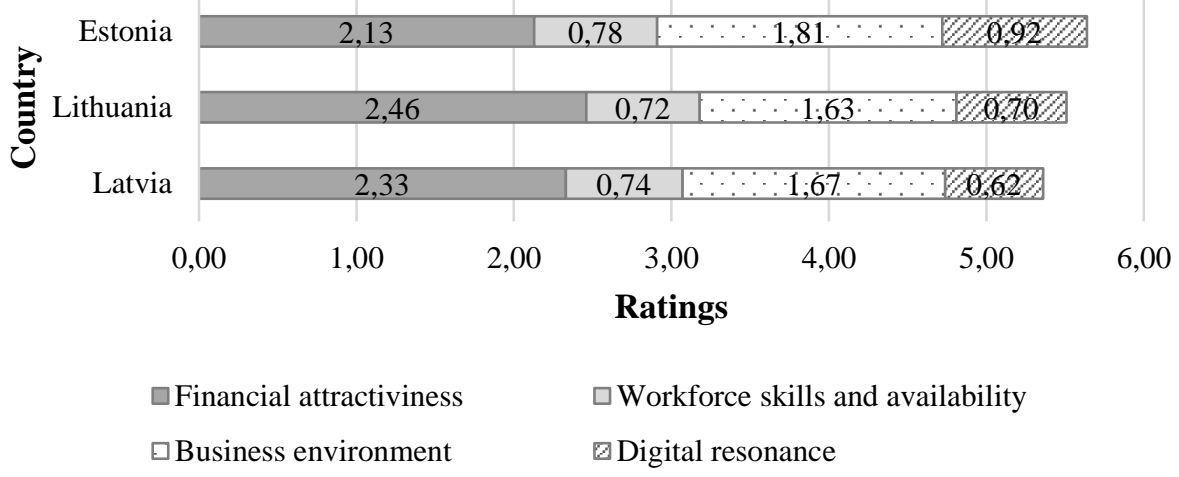

Source: authors' construction based on the 2019 Kearney Global Services Location Index data, 2019

Fig. 1. Attractiveness of Latvia, Lithuania and Estonia to global services in 2019

Overall, according to Figure 1, it could be concluded that the business environment and financial attractiveness in Latvia were rated as good among the Baltic States.

Social factors. The public have a misconception about the global business services sector, which was also pointed out by the experts interviewed. In other words, there was little or no public awareness of the 
sector, and the public associated it with call centres. Low value-added jobs or call centres - this was the most frequently given answer about the global business services sector in Latvia, seemingly consistently ignoring the fact that this was the sector that made one of the largest investments in important areas such as data science and robotics in recent years. Besides, few people knew about the high added value that companies contributed to the economy of Latvia (taxes paid, high earnings, insurance, good working conditions, social events etc.) and the fact that often these business centres employed highly qualified specialists.

It could be concluded that another of the most important social factors is the skills of the workforce. Estonia is viewed as more attractive than Latvia and Lithuania in terms of workforce skills and availability, and it is highly valued in terms of digital skills in particular (Digital resonance: the..., 2019). In relation to skills, it is very important to note the qualifications of employees. According to the 2019 report "Assessment of the Ecosystem of Latvian Start-ups, the Identification of the Current Situation and the Development of Proposals based Thereon" prepared by GatewayBaltic, several important elements in the field of ICT were emphasized, given that it was one of the most represented fields in the global business services sector. This report states that among the Baltic States, Lithuania had the largest number of employees in the ICT sector, yet the turnover of the sector was lower, which was due to the existence of global business service centres that operated as part of companies and did not generate value added in the sector. In Latvia, a large number of ICT employees were employed in shared service centres in particular. Although the report stated that Latvia had high potential for ICT outsourcing, Latvia, unlike the other Baltic States, had the largest number of active companies in the sector and was also a leader in terms of employment growth. Nevertheless, Latvia lacked at least 3000 ICT employees to meet its market needs (Latvijas jaunuznemumu ekosistemas..., 2019) and the digital gap still exists between the more developed Nordic European countries and the less developed Eastern European countries (Grinberga-Zalite G., Zvirbule A, 2020).

Language skills should also be considered with regard to skills, which is an important criterion for potential investors. Latvia as a whole was in the best situation in relation to both English and Russian language skills. The high number of English speakers is a clear advantage for Latvia (The most spoken..., 2020), given that English a working language in all global business service centres, or at least a language a potential employee should be able speak. It is also important to note the population's knowledge of the Russian language, and Latvia is the leader among the other Baltic States. It should also be noted that according to the data from ABSL Latvia, companies in the sector annually invest approximately EUR 10 million in personnel training (digital skills, foreign language skills etc.).

Currently, there is a tendency for business services to become geographically closer to the group companies. This is due to data security, and the work is also becoming increasingly complex. In this situation, it is very important that both business parties have a similar culture and understanding of quality. Besides, the experts interviewed admitted that the Scandinavians who most represented the global business services sector in Latvia, had similar cultural features, communication and understanding, which created a kind of guarantee of trust on their part when choosing Latvia.

Technological factors. In the global business services sector, IT systems are of great importance; however, the automation of systems, as well as the connection of internal and external IT systems is considered to be expensive, complicated and time-consuming. Accordingly, robotic process automation or RPA is an alternative used by companies in this sector. RPA means that robotic software is trained to perform operations in IT systems that humans used to do. It is mostly designed for mostly "repetitive" jobs that do not require human skills such as intuition. RPA is most commonly used for data entry, where the robot obtains electronic data and enters the data into other systems. The most typical examples are the 
entry and processing of invoices or customer data. RPA is also effective in data verification and validation, where it can verify the accuracy and adequacy of information. This approach could also be used for performing tasks with a time limit etc. The majority of business services centres have already implemented automated solutions at certain level. Few companies are still in the process of developing the most efficient tools to limit routine tasks, thus making space for more advanced business support activities. It is only a matter of time until all business services organizations will have automated processes to some extent. According to a study by ABSL Latvia (2020), currently $80 \%$ of all companies under analysis answered positively about robotic solutions in their organizations, while $8 \%$ were planning to use it in the future. Accordingly, companies have released their workforce to tackle much more complicated tasks with higher added value; this allows employees to be responsible for more interesting tasks while also earning a higher wage.

In addition, companies in the global business services sector also tend to introduce artificial intelligence, which is associated with computer functions that require human intelligence. The financial sector is considered to be one of the sectors where artificial intelligence has the greatest potential. Owing to artificial intelligence, according to the experts interviewed, it is possible to speed up transactions by using online chat robots that help customer service professionals.

Legal factors. At the end of 2019, ABSL Latvia, the Alliance of Real Estate Developers and others submitted proposals for the National Development Plan of Latvia for 2021 - 2027, which emphasized the role of foreign investors in the development of the national economy, including the global business services sector, and were aimed at ensuring the competitiveness of the country in the international arena and increasing the prosperity of the country's population. As a result, the National Development Plan of Latvia for 2021 - 2027 states that one of the courses of action is "Capital and the entrepreneurial environment", and it is necessary to contribute to the development of an environment that supports local and foreign investments.

In addition, it should be noted that although global business service providers operate under different legal forms (companies in the sector choose either the legal form of a branch of a foreign company or are registered as a limited liability company), their economic activities are governed by the legal framework for business in Latvia.

Environmental factors. The most important environmental factor is the favourable location or proximity to the Scandinavian countries, which is one of the main reasons why many companies of Scandinavian origin choose Riga as the most suitable location. First of all, there are very frequent flights to Stockholm, Oslo and other smaller cities from the Riga International Airport. The experts also pointed out that the location of Latvia was always highly valued, as well as the Riga International Airport, which served almost half of the region's passengers (44\%). In addition, it should be noted that according to the data from the Central Statistical Bureau of Latvia, there were 627487 residents in Riga region (2020). Given the large number of people living in regions close to Latvia's capital city, the majority of which work in Riga, it is more appropriate to consider the total population of Riga's surrounding area to be more than 1 million people. This gives Riga the status of the third largest city in Northern Europe. Besides, $61 \%$ of the population are in their working age. This explains why the vast majority of business service centres are based in Riga. Nevertheless, Latvia is still home to other cities where business service centres could be developed. The current situation shows that companies are being passive in trying to expand their operations in smaller cities of Latvia. Ventspils and Jekabpils have established their first business service centres (Business Services Sector..., 2020). 
Given the political, economic, legal, social and technological factors, it could be concluded that the global business services sector in Latvia has the potential to grow and develop owing to government support, available human skills, potential in ICT and the country's cultural and value similarities and geographical proximity to investors. The trends in technological progress are also important, as companies in the sector introduce new technologies, thereby creating a more technologically advanced general business environment in Latvia.

\section{Conclusions and proposals}

1) In Latvia, the global business services sector consists of centres of excellence, shared service centres, business process outsourcing, IT support and system maintenance services, research \& development centres. Although this sector has been developing fast in Latvia in recent years, accounting for $2.3 \%$ of GDP as well $8 \%$ of total service exports, the general public does not have a clear picture of it or has a misconception about it. This means that the association ABSL Latvia should do informative work and educate the public, informing the public about the sector's contribution to the national economy.

2) Relatively low labour costs as well as the establishment of the Association of Business Service Leaders in Latvia (ABSL Latvia), which is the only such an association in the Baltic States that defends the interests of this sector, are the factors contributing to the global business services sector in Latvia.

3) The potential of the global business services sector in Latvia is also characterized by its advantageous geographical location, especially from the perspective of Scandinavian investors (including in terms of cultural similarities), as well as the foreign language skills of potential employees, especially among young people.

4) Global business service providers, regardless of their legal form (most often a limited liability company or a branch of a foreign company) are governed by the legal framework for commercial activities as well as other binding regulatory enactments.

\section{Bibliography}

1. Aman, A., Yunus, Y.M., Maelah, R., Embong, Z., Mohamed, Z.M., Adznan, S., Ahmad, A.A., Khairuddin, Z.N., Fernandez, D. (2017). Talent Pool for Global Business Services: Industry Academia Collaboration. Asian Journal of Accounting and Governance, Volume 8, pp. 85-91.

2. Banoun, A., Dufour, L., Andiappan, M. (2016). Evolution of a Service Ecosystem: Longitudinal Evidence from Multiple Shared Services Centers Based on the Economies of Worth Framework. Journal of Business Research, Volume 69, Issue 8, August, pp. 2990-2998.

3. Bangemann, T.O. (2017). Shared Services in Finance and Accounting. New York: Routledge. p. 262.

4. Beaman, K.V. (2006). Common Cause: Shared Services for Human Resources. Austin, Texas: Futura Publishing LLC. p. 326.

5. Business Guide (2019). Retrieved: https://www.liaa.gov.Iv/lv/latvian-businessguide/liaa_business_guide_05062019.pdf Access: 14.01.2021.

6. Business Services Sector in Latvia 2020 (2020). Retrieved: https://site954860.mozfiles.com/files/954860/absl_latvia_20200429_epub-1.pdf Access: 14.01.2021.

7. Cheon, M.J., Grover, V., Teng, J.T.C. (1995). Theoretical Perspectives on the Outsourcing of Information Systems. Journal of Information Technology, Volume 10, pp. 209-219.

8. Dibbern, J. (2004). The Sourcing of Application Software Services: Empirical Evidence of Cultural, Industry and Functional Differences. New York: Physica-Verlag Heidelberg. p. 332.

9. Digital Resonance: the New Factor Influencing Location Attractiveness: The 2019 Kearney Global Services Location Index (2019). Retrieved: https://www.kearney.com/digital-transformation/gsli/2019-full-report Access: 14.01.2021.

10. Elston, T., MacCarthaigh, M. (2016). Sharing Services, Saving Money? Five Risks to Cost Saving when Organizations Share Services. Public Money \& Management, Volume 36, pp. 349-356.

11. Garson, D. (2008). Handbook of Research on Public Information Technology. IGI Global. p. 1066.

12. Grinberga-Zalite, G., Zvirbule, A. (2020). Digital Readiness and Competitiveness of the EU Higher Education Institutions: The COVID-19 Pandemic Impact. Emerging Science Journal, Volume 4, Issue 4, pp. 297-304. 
13. Kawshala, H. (2017). Theorizing the Concept of Core Competencies: An Integrative Model beyond Identification. International Journal of Scientific and Research Publications, Volume 7, Issue 2, February, pp. 253-256.

14. Koval, O., Nabareseh, S., Klimek, P., Chromjakova, F. (2016). Demographic Preferences Towards Careers in Shared Service Centers: A Factor Analysis. Journal of Business Research, Volume 69, Issue 11, November, pp. 4798-4803.

15. Krysinska, J., Janaszkiewicz, P., Prys, M., Rozewski, P. (2018). Knowledge Resources Development Process in Business Process Outsourcing (BPO) Organizations. Procedia Computer Science, Volume 126, pp. 1145-1153.

16. Latvijas jaunuznēmumu ekosistemas novertesana, pasreizēja stavokla identificesana un uz tas balstitu priekslikumu izstrade (Assessment of the Ecosystem of Latvian Start-ups, the Identification of the Current Situation and the Development of Proposals based Thereon) (2019) Retrieved: https://www.em.gov.Iv/sites/em/files/2019-03-27_11_46_18_jaunuznemumu_petijums1.pdf Access: 14.01.2021.

17. Leimeister, S. (2010). IT Outsourcing Governance: Client Types and Their Management Strategies. Wiesbaden: Springer Science \& Business Media. p. 368.

18. Licite, L., Janmere, L. (2017). Millennial Student Expectations towards Higher Education in Latvia. In: Engineering for Rural Development: proceedings of the international scientific conference, Jelgava, May 24 26, 2017 Latvia University of Agriculture, Faculty of Engineering. Jelgava, 2017. Vol. 16. Jelgava, pp. 14401445.

19. Liu, S., Wang, L., Huang, W. (2017). Effects of Process and Outcome Controls on Business Process Outsourcing Performance: Moderating Roles of Vendor and Client Capability Risks. European Journal of Operational Research, Volume 260, Issue 3, August, pp. 1115-1128.

20. Lupia, A. (2015). Delegation of Power: Agency Theory. International Encyclopedia of the Social \& Behavioral Sciences (Second Edition), pp. 58-60.

21. Marciniak, R. (2013). Choice between Outsourcing and Shared Services. Retrieved: https://www.academia.edu/10679042/Choice_Between_Outsourcing_And_Shared_Services Access: 14.01.2021.

22. Mclvor, R. (2005). The Outsourcing Process: Strategies for Evaluation and Management. Cambridge: Cambridge University Press. p. 335.

23. Oshri, I. (2011). Offshoring Strategies: Evolving Captive Center Models. Massachusetts: Massachusetts Institute of Technology. p. 280.

24. Oshri, I., Kotlarsky, J., Willcocks, L.P. (2015). The Handbook of Global Outsourcing and Offshoring 3rd edition. New York: Palgrave Macmillan. p. 365.

25. Pankowska, M. (2019). Information Technology Outsourcing Chain: Literature Review and Implications for Development of Distributed Coordination. Sustainability, Volume 11, Issue 5, pp. 1460-1488.

26. Perkune, L., Licite, L. (2019). Labour Market Expectations of Generation Y. In: Economic Science for Rural Development: proceedings of the international scientific conference, Jelgava, May $9-10,2019$ Latvia University of Life Sciences and Technologies. Faculty of Economics and Social Development, No 52: New Dimensions in the Development of Society. Home Economics. Finance and Taxes. Bioeconomy, pp. 119-126.

27. Richter, P.C., Bruhl, R. (2020). Ahead of the Game: Antecedents for the Success of Shared Service Centers. European Management Journal, Volume 38, Issue 3, June, pp. 477-488.

28. Richter, P.C., Bruhl, R. (2017). Shared Service Center Research: A Review of the Past, Present, and Future. European Management Journal, Volume 35, Issue 1, February, pp. 26-38.

29. Rothwell, A.T., Herbert, I.P., Seal, W. (2011). Shared Service Centers and Professional Employability. Journal of Vocational Behavior, Volume 79, Issue 1, August, pp. 241-252.

30. Senft, D. (2013). International Sourcing: A Method to Create Corporate Success. Wiesbaden: Springer Fachmedien Wiesbaden. p. 242.

31. Strikwerda, J. (2006). The Shared Service Centre: Change, Governance and Strategy Retrieved: https://www.researchgate.net/publication/228411106_The_Shared_Service_Centre_Change_Governance_and_ Strategy Access: 14.01.2021.

32. The most spoken languages in the European Union (2020). Retrieved: https://languageknowledge.eu/ Access: 14.01.2021.

33. Zhang, Y., Liu, S., Tan, J., Jiang, G., Zhu, Q. (2018). Effects of Risks on the Performance of Business Process Outsourcing Projects: The Moderating Roles of Knowledge Management Capabilities. International Journal of Project Management, Volume 36, Issue 4, May, pp. 627-639.

34. Zvejnieks, O. (2019). Strauji augosi, bet maz zinami - nozare, kas veido 1.9\% no IKP (Fast Growing but Little Known - an Industry that Accounts for 1.9\% of GDP) Retrieved: https://www.la.Iv/strauji-augosi-bet-nezinami Access: 14.01.2021. 